The Geneva Papers on Risk and Insurance, 14 (No. 53, October 1989), 360-370

\title{
Professional Liability Insurance in Scandinavia. The Liability of Accountants, Barristers and Estate Agents
}

\author{
by Göran Skogh*
}

\section{Introduction}

Professional liability insurance has become widely discussed in the latest decade, especially in the US. One reason is the rapid increase in claims paid and the "insurance crisis". In the Scandinavian countries there is also a trend towards increased professional liability claims, but it is not dramatic, and liability insurance is available at relatively small costs. These facts make a study of Scandinavian professional liability of interest. The operation of the Scandinavian system is however not easy to understand. A simple discription of professional liability in Scandinavia, and its associated institutions, is not very revealing. The problem is that the facts have to be related to a theoretical framework able to explain the phenomena observed. The traditional "pooling-of-risks" theory of insurance cannot serve this function. According to this theory, we would expect insurance for the coverage of large damages with relatively large deductibles because of administrative costs. ${ }^{1}$ We observe, however, the opposite; insurance is mandatory, deductibles are small and the coverage often maximized to relatively small amounts.

* Associate Professor at the Departments of Economics, the University of Lund, Sweden. Financial support from the FPG (Försäkringsbolaget Pensionsgaranti) is gratefully acknowledged.

1 The limited explanatory value of the "pooling of risks" theory of insurance has been discussed in the risk-management literature. According to the traditional theory of insurance the large profitmaximizing firms should self-insure minor losses in order to avoid the loading costs of insurance. However, property and liabilities of relatively low value are often insured. Another phenomenon that is difficult to understand as pure risk pooling is the purchase of insurance policies that cover the replacement of buildings when replacement costs exceed expected flows of future returns (Doherty 1985, p. 277). Individuals also tend to "over-insure"; with loading charges of 20-40 percent of premiums (Finsinger and Pauly, 1986, pp. 73 and 221) we would expect less insurance and larger deductibles than observed (Pashigian et al., 1966, Bernard Friedmann, 1974, Charles Stuart, 1983). Clifford Smith Jr. and J. B. Warner (1979), David Mayers and Smith (1981, 1982, 1987), and Brian Main (1982, 1983) argue that individuals in frictionless capital markets would adjust their portfolios in such a way that there would be no demand for a resource-consuming insurance industry; with well-functioning capital markets, insurance companies would have no obvious comparative advantage in diversification of risks over banks or corporate firms. It is argued instead that corporate insurance purchases may be motivated on several seperate ground such as (1) low-cost claims administration services, (2) assistance in assessment of the value of safety and maintenance projects, (3) an improvement in the incentives to 
In a recent paper, Skogh (1988) presents a transaction costs theory of insurance that can be used as an explanatory framework. This theory is presented in section II. In section III the theory is applied to professional liability. Section IV describes briefly the structure of the accountant's, barrister's and estate agent's insurance in Sweden, Denmark, Norway and Finland. The conclusions are presented in section $\mathrm{V}$.

\section{The transaction costs theory of insurance}

Traders faced with the problem of contracting realize that a complete contingent claim contract that regulates all possible outcomes is infeasible. This is due to the costs involved in identifying all events, negotiation, pricing, the documentation of corresponding contractual liabilities as well as the costs of enforcing the contract. The possibility that the obligations may not be fulfilled creates a credibility problem.

Contingencies that are too costly to regulate contractually may be insured or left without consideration. When a previously unconsidered risk is realized, liability must be settled ex post, for instance by a public court. When the risk is insured, it is sold (at a negative price) to a third party, the insurer. Hence insurance is an alternative to both costly contracting and to costly litigation.

For instance, assume that a manufacturer and a shipper enter into a contract for the transport of the manufacturer's machinery. They contract on amount, price, date of delivery as well as on some other basic items. However they do not contract on contingencies such as fire, storm and explosion since they have too little knowledge of the risks to be able to price liability and precautions and if there is a serious accident the liable party may not fulfil the agreement. Instead they add a clause stating that the transport has to be insured. Accordingly, a whole package of contingencies are transacted to an insurance company.

The insurance industry is specialized in contracts on "insurable" risks such as risks due to fires, storms, traffic accidents, and third-party liability. In the case of such risks there are usually a large number of specific risky events that can arise and a low probability that a specific event will occur. Low probabilities may give the specialized insurance firm a comparative advantage in writing contracts and in dealing with realized accidents. ${ }^{2}$ The insurer obtains information on the actuarial relation between damages, the presence of safety devices, level of deductibles, co-insurance, and costs of various claim settlement procedures. The insurers may therefore offer different policies at premiums that vary with the actuarial expected costs of precautions and other observables. An important property of the insurance contract is that it gives the insurer latitude to adjust or withold claims in accordance with the precautions taken.

undertake investments in safety and maintenance projects and (4) increased efficiency in the allocation of risk-bearing among the corporation's claimholders (Mayers and Smith, 1987, p. 46). A shortcoming in these theories is, however, that there is no distinction made between risk-management services and insurance. A risk-management expert can advise on how to draw up contracts, assist with safety projects and claims adjustments. Thus the demand of insurance is still to be explained, which is also the case with professional liability insurance.

${ }^{2}$ A number of empirical studies show that the minimum efficient scale in handling the insurable risks is relatively large, see e.g. Allen (1974) and Skogh (1982). 
An insurance policy contains a list of restrictions and limitations that specify the liabilities of the insurer and the involved parties. For instance, a shipping policy may state explicitly that the insurer is liable except when the shipped good is improperly packed, which would make the packing firm liable, or when the shipper is negligent, which would make the shipper liable. Hence the services of the insurance industry includes writing, pricing and enforcing liabilities as defined in the policies. This is largely a legal function.

It may be argued that a risk-management expert specialized in low-probability risks could advise the parties on how to draw up a contract and assist with safety projects and claim adjustments. Consequently there would be no demand for insurance policies by riskneutral agents. However, because of the low probability of each specific event, information is inevitably poor and this will also apply to information on the value of the advice. The implied principal-agent problem may be reduced by transferring the risk to the risk-manager who receives a payment $e x$ ante that covers expected claims and administrative costs. A contract that makes the risk-manager the residual claimant is in essence an insurance contract.

Assume that the shipper is willing to accept the liability of property damages during the transport. The manufacturer questions, however, the credibility or trustworthyness of the shipper and requires therefore some form of security. Assume for simplicity that there are only two options: A security issued by a bank and insurance. Which alternative is the best? Institutions that accept the risks of others must be credible themselves. Thus the bank and the insurer must be large enough to be able to fulfil the obligations. Similarly they must also have a long term interest in fulfilling ex ante expectations. Credibility is fundamental for future sales both to banks and insurers. Let us therefore assume that they are equally credible. There may nevertheless remain differences in their ability to price the risk accepted, and in the control of the moral hazard. The risk-taker must also be able to make the limits of its responsibility clear. It may, for instance, exclude criminal behavior and damages due to negligence by others.

In sum, the comparative advantage of the options depends on the institution's own credibility, its ability to price the risk accepted and its ability to constrain the moral hazard. This explains why insurance firms insure risks such as fire and storm, while banks may accept "business risks" related to their specialization in the evaluation of bankruptcy risks among borrowers.

Another conclusion that can be drawn from the example is that security issuers are insurers and vice versa. In this respect there in no fundamental difference between banks and insurers. The example also clarifies the interrelation between the pricing-of-liability problem and the credibility problem. It is rational to have an insurer as a residual claimant - it reduces the principal-agent problem and contributes to an efficient pricing and enforcement of liability. This presupposes of course, that the insurer is credible. Similarly, the best issuer of a security is the one who is credible and has a comparative advantage in pricing liability and in the control of moral hazard. This explains why the security issued (the residual claimant) and the one who prices the liability and controls the moral hazard is usually the same.

Qualitative evidence supports the theory. Important evidence consistent with the theory is provided by the details of actual insurance policies : Most of the text of an ordinary property and liability policy consists of a list of restrictions, conditions, and limitations that define the liability of the insurer and the involved parties under a large number of contingencies. These conditions are similar to conditions that might have been included in a 
contract, if the traders had themselves contracted on the matter. Moreover, contractual clauses frequently require trading parties to purchase insurance. Shipping contracts and standard loan contracts normally include a clause requiring that property and liability is insured. The same is true of rental and lease contracts. Covenants are commonly attached to bonds requiring the corporation to purchase insurance; thus instead of writing a contingent-claim contract that includes all precautions required to make the bond a safe asset, an insurance policy is purchased against a portion of the contingencies. ${ }^{3}$ Insurance clauses have a long tradition in the construction industry. ${ }^{4}$ Franchisors often require explicitly that franchisees are insured. These requirements are independent of whether or not the insured party is risk-averse - insurance is universally required to reduce costs related to contracting, control and conflicts.

Insurance is thus the market's response to the contractors problem of credibility and of pricing liability. An interesting question is whether the established insurance policies are efficient in the sense that they minimizes the transaction costs in trade. To the extent that the insurers work in a competitive environment, we would expect that this would be the case. There is, however, a considerable free-rider problem. If, for instance, the manufacturer and the risk-neutral shipper trust each other, the shipper may accept all risks and precautions listed in a standard transport insurance policy at a price lower than the insurance premium that includes administrative costs. Indeed, if some "normal" standard transport insurance policy is accepted as trade custom and a costless public justice system prevails, no risk-neutral party will insure..$^{5}$ However the costs of litigation, the problem of pricing the liability, the limited trust among traders, risk-aversion and mandatory requirments of insurance explain why most traders insure.

\section{Professional Liability Insurance}

The buyer of services offered by, for instance, an accountant is usually a firm, or rather its stock-holders. Other claimants on the firm such as employees and the tax collecting State may also have an interest in these services. For the sake of simplicity, let us assume only one customer (the firm, or the client of a barrister or an estate agent) and one seller, the professional.

To start with, we assume that there is no established trade custom or laws regulating the professional's liability. The parties must thus regulate the liability themselves. The problem is that a complete contingent claim contract is infeasible. One reason is that the parties do not have enough empirical experience to price all contingencies. For instance, the accountant may, at a price, be willing to accept liability for losses due to embezzlement that could have been detected by the accountant, or the real-estate broker may accept liability for losses due to incomplete information given by the broker. The customer has the most limited experience of embezzlements (or the benefits and costs of detailed information) and is thus more or less unable to value the offer. Therefore, it may be rational to sell (at a

\footnotetext{
${ }^{3}$ Smith and Warner (1979) first interpret insurance clauses as a means of reducing agency costs between bond-holders and equity-holders.

${ }^{4}$ Bunni 1986, pp. 13-15.

${ }^{5}$ Uninsured traders may also free-ride on others covering losses by, for instance, bankruptcy.
} 
negative price) the risk to an insurer specialized in the liability of professionals. Another reason for insurance is the problem of credibility. Will the parties be able to fulfil their obligations? If so, will they stick to the contract ex post of a loss, or will they try to reinterpret the liability in their own favour?

If the professional is risk-averse there is an additional value of insurance.

The private demand for insurance created by costly contracting, credibility problems and risk-aversion does not guarantee that everyone is insured. The individual professional may remain uninsured and thus free-ride on the liability standards established in the insurance policies. The uninsured may also free-ride on the reputation of the profession if they do not fulfil their obligations. Free-riding is thus a problem of the profession. This explains why professional associations usually require that their members are insured.

The professional association may also require to be an agent for its members when negotiating the terms of the insurance policy: There are economies of scale in contracting and there is a collective interest in uniform liability standards. It is efficient (profit maximizing) for the professional and the profession, to accept liability (and to include it in the policy) if the benefit due to increased demand is larger than the costs in terms of additional work and insurance premium.

The more precise interpretation of the professional liability takes place ex post on the settlement of the claim. The professional associations also act therefore as an agent for its members in relation to claim disputes. Note that the association is more suited than the individual to the protection of the collective professional interest ex post of an accident. The individual claimant will require as much as possible and the insured professional does not mind since the insurer pays. If the professional association instead participates in the claim settlement and argues for coverage of all claims, the association then accepts an expansion of the profession's liability and future premium increases for the members. Hence the professional association will argue for pay-outs that it regards as optimal for the profession.

A system with mandatory insurance bargained by the association, where the association is an agent at claim settlements, is more or less identical with a system where the professional association itself is the policy-holder: The association purchases its insurance and protects its interests in relation to claim settlements. ${ }^{6}$

It is in the interest of the professional association to have most liability included in the insurance policy. Otherwise, the policy would not completely define the liability of the professional - it is convenient for the professional association to control most liability matters via the claim settlement process. Moreover, by making most disputes between professionals and their customers an insurance matter, the association obtains valuable information on individual members. This is important because the all-inclusive and uniform liability insurance is open to moral hazard. The association must control its members and take disciplinary measures against the "black sheep".

For these reasons we would expect to find insurance policies that cover most professional liabilities. We will also expect small deductibles, because of the collective need to

\footnotetext{
${ }^{6}$ The association may also self-insure and thus act as insurer. This is the case when the association issues securities for members who harm their customers. However, in the modern economy with insurance companies who can economize on contracting cost and claim settlements, the professional association will presumably find it profitable to purchase insurance.
} 
clarify liability even in relation to small claims. The insurance coverage of large claims is of less collective importance as the small deductible is sufficient to make the claim an insurance matter. Large losses will also be insured freely by the risk-averse professionals. This explains the existence of collective insurance with small deductibles and a limited insurance amount, combined with complementary individual insurance for large claims, and for losses due to consultancy that are not part of the profession.

The State may intervene in the private formation of liability for several reasons. One is to protect third party interests. Another is to support the formation of liability by the professional associations and the insurers. Sanctions available to a professional association (warnings and exclusions) may be small relative to the benefits of opportunism or fraudulent behavior. Public supervision, public authorization, laws on mandatory insurance and mandatory membership of a professional organization and legally codified trade customs support the work of professional associations.?

Judgements by public courts are necessary as the ultimate source of conflict resolution when the liability is not settled by contracts or by insurance. The courts are thus complements and substitutes when the parties in the business are unable, at reasonable costs, to settle the liability themselves. A frequent use of public courts is thus an indicator of an inefficient private system for the formation of ethics and liability.

\section{The Scandinavian system}

\section{A. Accounts}

The duties of the Swedish accountants are regulated by law, primarily by the Book keeping Act, the Statutes of Accountants and the Stock-Company Act. The liability of the accountant is also regulated by contract law, tort law and criminal law. Accountants working for stock-companies have to be approved by the National Board of Trade, which also supervises the profession. The system of legal regulation is similar in Denmark and Norway. In Finland the Central Chamber of Commerce authorizes and supervises the accountants.

These laws together with public control, have partly the function of protecting third parties such as small stock-owners, employees and the State's interest in tax collection. In addition the laws codify and support the trade customs developed in the business. This is mostly done by general statutes - the accountant shall follow "good accounting practice" (god redovisningssed), which may be interpreted as equivalent to "the existing practice of a group of qualified and representative accountants" (Prop. 1975: 104 p. 148). The professional associations and the insurers have an important role in the interpretation of "good practice" and thus in the formation of liability.

In Sweden the approved accountants belong to one or more of the four existing professional associations. ${ }^{8}$ Denmark and Norway have two associations, one for accountants

\footnotetext{
${ }^{7}$ Evidence of the complexity and richness of standards produced in the industry, and of its relation to law, can be studied in textbooks on insurance law (Jess 1986, Keeton 1971, Colinvaux, 1984).

${ }^{8}$ The associations are the Association of Authorized Accountants FAR (Föreningen för Auktoriserade Revisorer), The Swedish Society of Accountants, SRS, (Svenska Revisorssamfundet), The Swedish Society of Accounting Consultants, SRF, (Sveriges Redovisningskonsulters Förbund) and The Swedish Association of Accountant firms, SBRF (Sveriges Bokförings- och Revisionsbyråers Förbund).
} 
authorized by the State and one for "registrated" accountants. In Finland there are two associations, one for authorized and one for "approved" (godkända) accountants. In the bylaws of the associations, it is stated (with somewhat different wording) that its members shall follow "good accounting practice".

Collective insurance negotiated by the professional associations is the predominant form of insurance in Scandinavia. In Sweden, the accountants liability insurance is individual, but collectively negotiated by the professional association in question and the insurer. The professional associations require that their members are insured. The Swedish law states that an authorized accountant must issue a security or insure. Denmark has similar rules. In Norway and Finland there is no legal obligation to insure, but the Norwegian associations offer collective insurance and the Finnish Chamber of Commerce requires insurance.

The associations act as agents for their members in insurance claim settlements. In Sweden, joint committees with members from the professional association and the insurer discuss practically all insurance claims. In addition, the principal insurer, Skandia, has an advisory panel of appeal.

The insurance covers liability for economic losses due to negligence or crime in relation to professional activity. A first point to be considered in the joint committees is whether the work (e.g. consultancy) that resulted in the claim should be regarded as a part of the accountant's profession. If it is, and the accountant is negligent, the loss is covered by the insurance. In this process, the distinction between the accountant's profession and an other profession is settled. The limit of the professionals duty to take care is also clarified and priced. If, for instance, the representants of the insured argue that the claim should be covered, they also accept its impact on future premiums. On the other hand, if they argue that the accountant has not been negligent, they limit the scope of the profession. ${ }^{9}{ }^{10}$

In Sweden, the individual premium for the mandatory insurance varies between 1.000 2.800 SEK a year. The insured amount is maximized to an annual sum of around 300.000 SEK for a single accountant. The deductibles are small. The Swedish deductibles vary between 15.000 SEK and 30.000 SEK (Eklund 1988). ${ }^{11}$ The picture is about the same in the other countries. However, Norway has a deductible on 25 percent of the insurance amount and Finland has a uniform insurance amount of 250.000 FMK.

The individual accountant may purchase additional private insurance to cover large claims and liability not included in the accountant's profession.

9 The main insurer Skandia has around 50 claims a year, which are examined together with the Swedish associations. There is a development towards an extension of liability and thus a widening of the accountants profession (Moberg, 1986, p. 161).

${ }_{10}$ The different associations negotiate separately on premiums, deductibles and the insurance amount, although they cooperate on the general standards contained in the policies. Since 1932 the Association of Nordic Accountants (Nordiska Revisorsförbundet) have worked for common standards on "good practice".

${ }^{11}$ In a recent memorandum, The National Board of Trade (Kommerskollegium, 1988) argued that the deductibles ought to be even smaller to extend the mandatory insurance in order to include practically all disputes on accountants' liability under the insurer's umbrella. A more uniform legal practice is thereby supposed to follow. 


\section{B. Barristers}

Scandinavian lawyers that professionally defend clients in public courts are entitled barristers (advokater). The barrister has to be a member of the "Association of Barristers" (Advocatsamfundet). There is only one such association in each country.

The barrister's work and liability is regulated by procedural law and criminal law. Parts of the bylaws of the Scandinavian associations of barristers are also regulated by law. ${ }^{12}$ In addition to the relatively well defined duties given by law, the barristers are required to act in accordance with "good practice". The Board of the Association of Barristers interprets the meaning of "good practice". The standard used is related to the level of care taken in the profession. The process by which the liability takes form resembles that described above for the accountant.

All Scandinavian countries have mandatory liability insurance for barristers. In Sweden the Association of Barristers is the buyer of insurance. ${ }^{13}$ In Denmark and Finland, the barristers purchase insurance individually, although mostly through the same insurance company. Some Norwegian barristers choose individual insurance.

In Sweden the insurer investigates the damage and settles the claim together with the Association of Barristers. In complicated cases they may consult the Board for Liability Insurance for Barristers. This Board is set up by members elected by the Association of Barristers and by the insurance company. The Board investigates whether the damage is part of the barrister's business, if the insurance covers the damage and if the insured is liable. Finland has a similar board. Denmark and Norway have not formalized this cooperation to the same extent.

The policies cover all economic losses due to the barrister's professional activities. The deductibles are small. Practically all disputes regarding barrister liability is thus settled within the system. The annual insurance premium for a barrister is small relative to the sales. The mandatory insurance amount is also limited to relatively small claims. The average claim is relatively small. ${ }^{14}$

The barristers may add private insurance for larger losses and for liability that is unrelated to the barrister's profession.

\section{Estate Agents}

The business of an estate agent is regulated by common trade laws and the specific statutes of the profession. In Sweden, 600 out of 2000 are authorized by the National Board of Trade. All brokers have to be registered. Registration and supervision are administered by the public authorities at the county level (läns-styrelserna). The Finnish system is close to the Swedish. In Denmark the Ministry of Commerce and in Norway the Ministry of Finance supervises the profession.

12 Norway is an exception with no public regulation of the professional association.

${ }^{13}$ Swedish barristers purchased private liability insurance before it was mandatory. Since 1985 the liability insurance in Sweden is collective. Before that there was a collective fund for compensation of damages due to criminal behavior of barristers.

${ }^{14}$ For Sweden the 1988 figures are: deductible 5000 SEK, premium 2.200 SEK and the insurance amount 3 million SEK (Eklund 1988). 
In Sweden there are two professional associations. The authorized estate agents in Denmark have had a single association since 1912 and there are three other small associations. In Norway and Finland the picture is about the same. The associations bylaws state that the association is required to establish rules for the profession and promote "good practice", which includes a duty to inform both the seller and the purchaser of the property on all relevant matters.

Collective insurance predominates. Liability insurance is a legal requirement in Sweden. The authorized estate agents have to be insured in Norway. In Finland and Denmark there is no legal requirement for insurance. However, the associations offer insurance. In 1989 a new law in Finland will introduce the same legal requirements as in Sweden.

The claims are settled in cooperation between the insured (the association) and the insurer. In Sweden, the parties may complain to a board of appeal. In the other countries, cooperation between the associations and the insurers is less formalized. Few cases are taken up by the courts.

The liability insurance covers economic losses due to the estate agent's business liabilities. The deductibles are relatively small. In Sweden, there is a co-insurance rate of twenty percent. In Denmark and Norway, the co-insurance rate is ten percent. In Finland the deductible is 1000 FMK. The insurance amount varies in Sweden between 500.000 SEK and one million SEK. In Denmark and Norway, the insurance amounts are larger (4-5 million SEK). The individual estate agent is free to add insurance on a private basis.

There are no unified statistics on claims paid. However the general picture is clear. The largest association in Sweden had 72 claims reported during the years 1984-87 with an average cost per claim of 14.000 SEK. The figure is an underestimate because of still unreported and not completed settlements. The final number will however not change the picture dramatically. In Denmark the authorized brokers have around 180 claims a year with an average pay-out of $8.300 \mathrm{DKR}$. In Norway the total pay-out increased from one million NEK in 1986 to 2.3 million in 1987 (Eklund, 1988).

\section{Conclusions}

Professional liability insurance for Scandinavian accountants, barristers and estate agents can be divided into two parts. One is the individually demanded insurance that covers large liability claims over and above the coverage of the mandatory insurance. This insurance can be explained by the traditional theory of risk-aversion.

The mandatory insurance covers all economic losses (up to the insured amount limit) due to negligence in professional work. The deductibles are small and the premiums are usually less than one percent of the yearly turnover of the professional. This insurance cannot be explained by the pooling-of-risks theory of insurance. The rationale for the insurance is instead that the purchase of a policy reduces the costs of contracting. Insurance also contributes to business credibility.

Due to the economies of contracting on insurance policies and to the problem of freeriding by non-insured professionals, professional associations require mandatory insurance and act as agents for their members in negotiations on the price and coverage of the insurance policy and in the claim settlement process. In this process, the liability of the profession is priced and settled. 
According to the traditional theory of insurance, and to the established Law and Economics doctrine, liability is settled by the traders contracts, by the courts or by statutes. Given the liability fixed in one of these ways, the risk-averse individual may insure. In this world, the insurer has no active role in the formation of liability. Here we find that the insurers are active in the formation of liability while the courts and the legislators have a limited role. An important function of the law is to support "good practice" in the profession, which is, to a large extent, formed by the associations in cooperation with the insurers. The law usually requires mandatory insurance, registration or authorization etc. that supports the efforts of the associations.

The courts influence the professional liability, perhaps most strikingly for barristers who work in the court-room. For accountants and for estate agents, the courts are of minor importance. Few cases are taken up in courts and when they are, the courts often try to interpret "good practice".

The remaining legal intervention in the private formation of professional liability is mainly due to the protection of third parties. For instance, the interests of the State in tax collection and the interest of minor shareholders have given rise to legal rules regarding accountants' liability. The barristers duties are, for obvious reasons, to a large extent regulated by procedural law. The duty of estate agents to disclose is part of consumer protection legislation in Sweden etc.

A final question is whether the Scandinavian system is efficient in the sense that it sets professional liability at a socially optimal level. Some facts indicate a positive answer to this question. The professional associations are, together with the insurers, the most competent parties in society as far as the evaluation and pricing of professional liability is concerned. The professional associations have also the socially correct incentive to limit the liability of the professional to the level where the benefit - in terms of increased demand for the professional services - equals the marginal cost in terms of increased insurance premiums and precautions. Another indicator of the efficiency of the Scandinavian system is the few cases taken up by the courts. A comparison could be made, for instance, with a system of individual insurance and claim disputes in public courts without the representation of professional associations. The claimant will try to get as much as possible and the insurer will make a restrictive interpretation of the insurance contract. The court has usually only limited competence in evaluating the future consequenses for the profession. Hence, a general willingness to compensate the victim may increase liability and the insurance premiums without limit.

A negative effect of the mandatory, uniform and all-inclusive insurance is moral hazard. To compensate for this, the social control by professional associations must be considerable. Disciplinary measures must also be taken against disobedient members. Hence the individual professional is highly dependent on the association of which he is forced to be a member. Another negative effect is the monopolistic power of the associations - they are not only able to control liability and thus the content of the professional services, but sometimes its price as well. 


\section{REFERENCES}

ALLEN, R. F. (1974). Cross Sectional Estimates of Cost Economies in Stock Property-Liability Companies. The Review of Economics and Statistics. Vol. LVI, no. 1, 100-103

BUNNI, N. G. (1986). Construction Insurance. Elsevier Applied Science Publishers LTD. London and New York.

CARLBERG, A. C. (1985). Några problem vid ansvarsförsäkring för ren förmögenhetsskada orsakad av advocat och revisor i deras verksamhet. Juridiska fakulteten, Uppsala University, memo.

COLINVAUX, R. (1984). The Law of Insurance. 5th edition. Sweet and Maxwell, London.

DOHERTY, N. (1985). Corporate Risk Management. A Financial Exposition. MacGraw Hill. New York.

EKLUND, L. (1988). Professionsansvar och ansvarsförsäkring i Norden.

FINSINGER, J. and PAULY, M. (1986). The Economics of Insurance Regulation. A Cross-National Study. Macmillan.

FRIEDMAN, B. (1974). Risk Aversion and the Consumer Choice of Health Insurance Option. Review of Economics and Statistics 56, 209-214.

JESS, D. C. (1986). The Insurance of Commercial Risks: Law and Practice. Butterworths. London.

KEETON, R.E. (1971). Basic Text on Insurance Law. West Publishing Company. St. Paul Minn.

Kommerskollegium (1988). Ansvarsförsäkring för Revisorer. Memo.

MAIN, B. G. (1982). Business Insurance and Large, Widely-held Corporations. The Geneva Papers on Risk and Insurance, 237-247.

MAIN, B. G. (1983). Why Large Corporations Purchase Property/Liability Insurance. California Management Review. Vol. XXV, no. 2, 84-95.

MAYERS, D. and SMITH, Jr., C. W. (1981). Contractual Provisions, Organizational Structure, and Conflict Control in Insurance Markets. Journal of Business. Vol. 54, no. 3, 407-434.

MAYERS, D. and SMITH, Jr., C. W. (1982). On the Corporate Demand for Insurance. Journal of Business. Vol. 55, no. 2, 281-295.

MAYERS, D. and SMITH, Jr., C. W. (1987). Corporate Insurance and the Underinvestment Problem. The Journal of Risk and Insurance, no. 1, 45-54.

MOBERG, K. (1986). Bolagsrevisorn. Nordstedt. Stockholm.

PASHIGIAN, B. P., SCHKADE, L. L. and MENEFEE, G. H. (1966). The Selection of an Optimal Deductible for a Given Insurance Policy. Journal of Business 39, 35-44.

Prop. 1975: 104, p. 148.

ROOS, C. M. (1981). On Insurer Generosity. Scandinavian Studies in Law.

SKOGH, G. (1982). Returns to Scale in the Swedish Property-Liability Insurance Industry. The Journal of Risk and Insurance, 218-228.

SKOGH, G. (1988). A Different Theory of Insurance - Contracting Impediments and Costs. Mimeo.

SMITH, Jr., C.W. and WARNER, J.B. (1979). On Financial Contracting. An Analysis of Bond Covenants. Journal of Financial Economics, 117-161.

STUART, C. (1983). Pareto-Optimal Deductibles in Property. Liability Insurance: The Case of Homeowner Insurance in Sweden. Scandinavian Actuarial Review, 227-238. 